\title{
Classification of soils derived from amphibolite parent material in south-western Nigeria
}

\author{
B. A. OSEI \& T. A. OKUSAMI \\ Department of Soil Science, Obafemi Awolowo University, Ile-Ife, Nigeria (B.A.O. 's present address: \\ Department of Soil Science, School of Agriculture, University of Cape Coast, Ghana)
}

\section{SUMMARY}

Soils formed from amphibolite parent material in southwestern Nigeria were characterized and classified according to FAO/UNESCO soil map legend and USDA Soil Taxonomy. The soils had characteristically low silt content. Clay and fine sand contents were high. The soils varied from slightly acidic to acidic. Organic carbon, extractable phosphorus and total nitrogen contents decreased with increasing depth. Cation exchange capacity (by $\mathrm{NH}_{4} \mathrm{OAc}$ ) values of the soils ranged from 2.32 to $15.19 \mathrm{cmol}(+) / \mathrm{kg}$ soil. Base saturation (on $\mathrm{CEC}$ by $\mathrm{NH}_{4} \mathrm{OAc}$ ) basis) values were quite high (35.4-87.7\%). According to FAO/UNESCO soil map legend, the soil at the summit was Rhodic Ferralsol while the soil of the upper slope belonged to Ferric Acrisol. Soils of the middle and lower slopes of the toposequence were classified as Rhodic Nitisol and Haplic Lixisol respectively. The valley bottom soil was Gleyic Lixisol. All the soils belonged to Ultisol of Soil Taxonomy except the soil of the summit which was classified as Oxisol.

Original scientific paper. Received 19 Jan 93; revised 17 Mar 94.

\section{Introduction}

It has been observed that great demands are being made on the soils of tropical Africa to meet the needs for food and fibre of a rapidly-expanding population (Harpstead, 1974). Ojanuga (1975) also reported that the growing population of Nigeria has called for the need to change the existing smallscale, shifting cultivation system to a large-scale, continuous cultivation in order to provide enough food. The success of the new system, according to Ojanuga (1975), will depend on a good knowledge of the soils which are a unique base resource

\section{RÉSUMÉ}

OSEI, B. A. : Classification de sols provenant de matiére parentale amphibolite au sud-onest du Nigéria. Les sols formés de matière parentale amphibolite au sud-ouest du Nigéria étaient caractérisés et classifiès selon la légende de la carte du sol de FAO/UNESCO et le sol taxonomie de USDA. Les sols avaient une contenance de limon typiquement faible. Les contenances d'argile et de sable fin étaient élevées. Les sols variaient de légèrement acide a acide. Les contenances de carbone organique, de phosphore extractible et d'azote total diminuaient avec la croissance en profondeur. Les valeurs de la capacite (par $\mathrm{NH}_{4} \mathrm{OAc}$ ) d'échange de cation des sols se sont rangées de 2.32 à 15.19 cmol $(+) / \mathrm{kg}$. de sol. Les valeurs de saturation base (base sur CEC par $\mathrm{NH}_{4} \mathrm{OAc}$ ) étaient assez élevées (35.4 -87.7 pour cent). Selon la légende de la carte du sol de FAO/UNESCO, le sol au sommet était Rhodic Ferralsol alors que le sol a la montée de l'inclinaison apartenait à Ferric Acrisol. Les sols du milieu et de la descente des inclinaisons de la toposéquence étaient respectivement classifiés comme Rhodic Nitisol et Haplic Lixisol. Le sol au fond de la vallée était Gleyic Lixisol. Tous les sols appartenaient à ultisol de sol taxonomie sauf le sol au sommet qui était classifié oxisol.

for agricultural production.

Soils of south-western Nigeria have been studied and the primary objective of such studies especially in central-western Nigeria in the early 1950 s was to solve the problems posed by poor cocoa yield (Vine, 1951). Despite the early studies of the soils, little is still known of the genesis of some soils of south-western Nigeria (Ojo-Atere \& Oladimeji, 1983) possibly because fundamental pedological research has been minimal. There is also scarcity of detailed soil profile descriptions of soils of the tropics in the literature, according to 
Beinroth(1982).

Harpstead (1974) observed that soil survey which is fundamental to land-use planning is lacking in Nigeria except for few places where surveys of reconnaissance type are available. Harpstead (1974) further reported that most of the existing surveys in south-western Nigeria were not made with the intention of classifying the soils according to the Soil Taxonomy system. In addition, a study by Periaswamy \& Ashaye (1982) revealed that there is no proper classification of soils of southwestern Nigeria according to Soil Taxonomy and FAO/UNESCO soilmap legend.

The objective of the study, therefore, was to consider the appropriate placement of the soils formed from amphibolite in south-western Nigeria according to the revised Soil Taxonomy (Soil survey Staff, 1987) and FAO/UNESCO (FAO-UN, 1988) soil map legend.

\section{Materials and methods}

The Itagunmodi area was selected for the field work. The area lies approximately on latitude $7^{\circ} 34^{\prime} \mathrm{N}$ and longitude $4^{\circ} 37^{\prime} \mathrm{E}$ (Fig. 1). Rainfall distribution for the study area is presented in Table 1 . The rocks of the area belong to the amphibolite complex (Ajayi, 1980). The native vegetation which was formerly rainforest has given way to secondary forest and shrubs as a result of continuous cultiva-

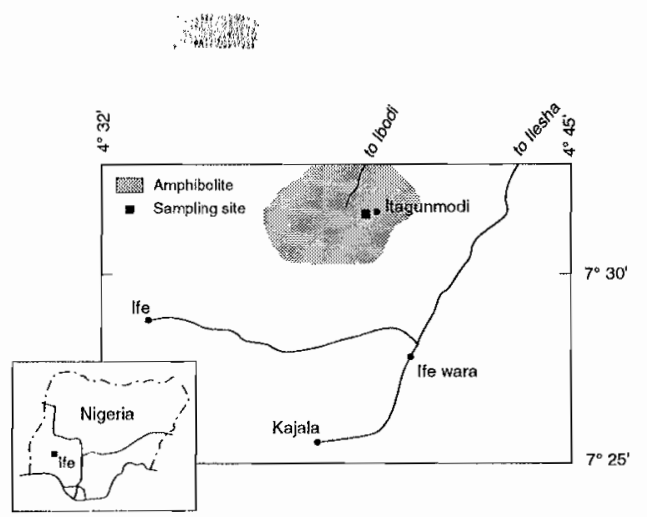

Fig. 1. Site location and geology of the sampling site tion.

\section{Field work}

Five soil profile pits were excavated along a toposequence. The soil profile pits were sited at the summit, upper slope, middle slope, lower slope and valley bottom (Fig. 2). The elevations and slopes of each profile pit were measured. The soil horizons were described according to the guidelines for soil profile description by FAO (1977) and the horizon designations of Soil Survey Staff(1981) were used. Bulk soil samples were collected from

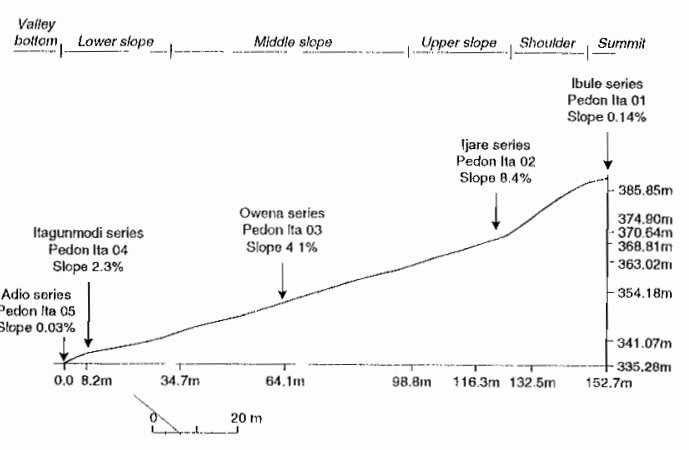

Fig. 2. Landform and location of soil profiles in toposequence

each horizon.

\section{Laboratory analyses}

The soil samples were air-dried, passed through a 2-mm sieve and then subjected to physical and chemical analyses. Particle size distribution was determined by the hydrometer method (Boyoucos, 1962) by dispersing in 5 per cent sodium hexametaphosphate. Soil $p \mathrm{H}$ was measured in soilwater suspension at 1:1 soil : solution ratio using glass electrode $p \mathrm{H}$ meter. Soil organic carbon was determined by Walkley-Black (1934) dichromate titration method and total nitrogen was determined by macro-Kejldahl method (Bremner, 1965). Extractable phosphorus was measured by Bray No. 1 method (Bray \& Kurtz, 1945). Extractable acidity 
TABLE 1

Rainfall Distribution (in $\mathrm{mm}$ ) of the Study Area

\begin{tabular}{rrrrrrrrrrrrrr}
\hline & Jan & \multicolumn{1}{c}{ Feb } & \multicolumn{1}{c}{ Mar } & \multicolumn{1}{c}{ Apr } & May & \multicolumn{1}{c}{ Jun } & Jul & Aug & Sep & Oct & Nov & Dec & Annual \\
\hline 1980 & 0.0 & 7.1 & 27.3 & 81.7 & 152.1 & 105.9 & 181.0 & 233.2 & 337.1 & 255.2 & 89.5 & 1.9 & 1472.0 \\
1981 & 0.0 & 39.7 & 69.9 & 177.1 & 104.1 & 209.9 & 174.7 & 84.7 & 259.6 & 241.6 & 17.4 & 0.0 & 1378.7 \\
1982 & 60.1 & 38.7 & 50.2 & 128.3 & 190.8 & 160.21 & 66.0 & 39.9 & 146.5 & 191.3 & 8.3 & 0.0 & 1077.3 \\
1983 & 0.0 & 2.6 & 0.5 & 108.8 & 158.7 & 198.1 & - & 142.7 & 174.6 & 54.3 & 0.0 & 25.3 & 865.6 \\
1984 & 0.0 & 11.3 & 70.0 & 144.1 & 162.5 & 276.6 & 169.9 & 278.2 & 223.6 & 231.8 & 0.0 & 0.0 & 1568.0 \\
1985 & 2.6 & 0.0 & 75.1 & 99.7 & 229.8 & 336.1 & 342.6 & 103.9 & 317.9 & 103.7 & 17.5 & 3.8 & 1632.7 \\
1986 & 15.3 & 34.3 & 97.4 & 92.3 & 174.2 & 93.1 & 163.6 & 43.3 & 222.9 & 182.2 & 8.6 & 0.0 & 1127.2 \\
1987 & 2.6 & 3.2 & 50.5 & 80.2 & 194.1 & 92.2 & 182.2 & 249.3 & 219.0 & 163.7 & 0.0 & 2.7 & 1239.7 \\
1988 & 0.0 & 51.8 & 109.4 & 170.6 & 112.2 & 259.1 & 290.9 & 145.0 & 293.9 & 252.5 & 6.9 & 1.6 & 1693.3 \\
1989 & 0.0 & 0.0 & 93.0 & 84.8 & 225.6 & 188.0 & 204.9 & 214.2 & 218.2 & 195.1 & 4.8 & 1.3 & 1429.9 \\
\hline
\end{tabular}

Source: Obafemi Awolowo University Teaching and Research Farm

- Data not available

was determined by BaCl-TEA $p \mathrm{H} 8.2$ method. Exchangeable bases $\left(\mathrm{Na}^{+}, \mathrm{K}^{+}, \mathrm{Ca}^{2+}, \mathrm{Mg}^{2+}\right)$ were extracted by $\mathrm{NH}_{4} \mathrm{OAc}$ at $p \mathrm{H} 7$. Potassium and sodium extracted were determined by flame photometer while calcium and magnesium were measured by atomic absorption spectrophotometry. Cation exchange capacity of the soils was obtained by the sum of cations (Peech et al., 1974) and $\mathrm{NH}_{4} \mathrm{OAc}$ method (Chhabbra, Pleysier \& Cremers, 1975).

\section{Soil mineralogy}

In a previous study by Osei (1992), the dominant clay mineral of the soils was found to be kaolinite. Weatherable minerals identified were feldspar and hornblende. Ibule, Ijare, Owena and Itagunmodi series had less than 10 per cent weatherable mineral contents while Adio series contained more than 10 per cent weatherable minerals (Osei, 1992).

\section{Results and discussion}

Morphological characteristics of the soils

Morphological characteristics of the soil profiles are presented in Table 2 and the various soil series identified by landscape position are also shown in Fig. 2.

The reddish hues (2.5 YR) of the subsoils of the soil profiles at the summit, shoulder, upper and middle slopes of the toposequence were evidences of their good drainage. The reddish colour of the well-drained soils might be due to the presence of hematite as explained by Lietzke (1966), Davey, Russel \& Wilson (1975) and Bigham et al. (1978). As moisture level increases and drainage becomes poorer, hues become yellower. The decrease in redness of poorly-drained soils can be attributed to increasing hydration of iron contents (Torrent $e t$ al., 1983). The mottled saprolites of the $\mathrm{C}$-horizons of some of the soil profiles (e.g. Ita 03) reflected the heterogenous composition of ferromagnesian minerals of the parent material as explained by Folster, Moshrefi \& Ojanuga (1971).

\section{Physical properties}

Table 3 displays particles size distribution of the soils studied. The content of materials greater than $2 \mathrm{~mm}$ varied from 0.0 to 59.1 per cent and the upper members of the toposequence had higher values. Sand content ranged from 27 to 67 per cent. It decreased with increasing depth to a minimum in the B-horizon and then increased in the C-horizons. All the soils had higher proportions of fine sand fraction which has been found to be a characteristic 
TABLE 2

Morphological Characteristics of the Soils Studied

\begin{tabular}{|c|c|c|c|c|c|c|c|}
\hline Horizon & $n$ Depth $(\mathrm{cm})$ & $\begin{array}{l}\text { Munsell colour } \\
\quad(d r y)\end{array}$ & Mottles & Texture & Structure & $\begin{array}{l}\text { Consistency } \\
\text { (moist) }\end{array}$ & $\mathrm{Fe}$ concretions \\
\hline Pedon & Ita 01: & Ibule Series & & & & & \\
\hline Apes & $0-7$ & $2.5 \mathrm{YR} 4 / 4$ & - & GRVSC & $\mathrm{M} 2 \mathrm{C}$ & VVFR & Few \\
\hline $\mathrm{ABc}$ & $7-22$ & 2.5 YR $4 / 4$ & - & GRVSC & M2SBK & VFR & V. Freq. \\
\hline B & $22-64$ & 2.5 YR $4 / 6$ & - & GRVC & M2SBK & VFI & V. Freq. \\
\hline
\end{tabular}

Pedon lta 02: $\quad$ ljare Series

$\begin{array}{lcclcccc}\text { Apc } & 0-8 & 5.0 \text { YR 5/2 } & - & \text { GRVSC } & \text { M2C } & \text { VFR } & \text { V. Freq. } \\ \text { BAc } & 8-40 & 2.5 \text { YR 4/6 } & - & \text { GRSCL } & \text { F3SBK } & \text { VFI } & \text { Frequent } \\ \text { Btcl } & 40-70 & 2.5 \text { YR 4/6 } & - & \text { GRC } & \text { F3SBK } & \text { VFI } & \text { Frequent } \\ \text { Btc2 } & 70-100 & 2.5 \text { YR 5/6 } & - & \text { GRC } & \text { F3SBK } & \text { VFI } & \text { Frequent } \\ \text { Btc3 } & 100-140 & 2.5 \text { YR 4/6 } & - & \text { GRC } & \text { F3SBK } & \text { VFI } & \text { Frequent } \\ \text { Cc } & 140-226 & 50 \text { YR 6/8 } & - & \text { SC } & \text { F3SBK } & \text { FRFI } & \text { V. Few }\end{array}$

Pedon Ita 03: Owena Series

$\begin{array}{lccccccc}\text { Ap } & 0-4 & 2.5 \text { YR 4/4 } & - & \text { C } & \text { M2C } & \text { FRFI } & \text { - } \\ \text { AB } & 4-44 & 2.5 \text { YR 4/6 } & - & \text { C } & \text { M2C } & \text { FRFI } & \text { V. Few } \\ \text { BAc } & 44-80 & 2.5 \text { YR 4/6 } & - & \text { C } & \text { M2SBK } & \text { FRFI } & \text { V. FeW } \\ \text { Btc1 } & 80-117 & 2.5 \text { YR 4/6 } & - & \text { C } & \text { M3SBK } & \text { FRFI } & \text { Frequent } \\ \text { Btc2 } & 117-149 & 2.5 \text { YR 4/6 } & - & \text { GRC } & \text { M3SBK } & \text { FRFI } & \text { Few } \\ \text { BCc } & 149-189 & 2.5 \text { YR 5/8 } & - & \text { SCL } & \text { M3SBK } & \text { FRFI } & - \\ \text { C } & 189-249 & 2.5 \text { YR 4/6 } & 10 \text { YR 8/6 } & \text { SC } & \text { M2SBK } & \text { FRFI } & -\end{array}$

Pedon Ita 04: Itagunmodi Series

\begin{tabular}{lccccccc} 
Ap & $0-3$ & 5.0 YR 4/3 & - & SCL & M2C & VFR & - \\
BA & $3-11$ & 2.5 YR 4/6 & - & SC & F2SBK & FRFI & - \\
B & $11-70$ & 2.5 YR 4/6 & - & C & F2SBK & FRFI & - \\
Bt1 & $70-133$ & 2.5 YR 4/6 & - & C & M2SBK & FRFI & - \\
Bt2 & $143-183$ & 2.5 YR 4/6 & - & C & M2SBK & FRF1 & - \\
C & $183-223$ & 2.5 YR 4/6 & - & SC & F2SBK & FRFI & - \\
Pedon Ita $05:$ & Adio Series & & & & & \\
Ap & $0-5$ & 10 YR 4/2 & - & L & M2C & FRFI & - \\
Bt1 & $5-44$ & 7.5 YR 5/4 & 10 YR 5/8 & SCL & F2SBK & FRFI & - \\
Bt2 & $44-70$ & 10 YR 5/3 & 10 YR 5/8 & C & F2SBK & FRFI & - \\
Bt3 & $70-143$ & 10 YR 5/3 & 7.5 YR 7/8 & C & M3SBK & FRFI & - \\
BC & $143-183$ & 10 YR 5/3 & 7.5 YR 7/8 & C & M3SBK & FRFI & - \\
C & $183-223$ & 10 YR 6/8 & 10 YR 5/8 & SC & F2SBK & FRFI & - \\
\hline
\end{tabular}




\begin{tabular}{lll}
\hline Texture & Structure & Consistency (moist) \\
GR = Gravelly & $1=$ Weak & VFR = Very friiable \\
GRV = Very gravelly & $2=$ Moderate & VFI = Very firm \\
S $=$ Sand & $3=$ Strong & FRFI = Friable firm \\
C $=$ Clay & F $=$ Fine & \\
SC $=$ Sandy clay & $\mathrm{M}=$ Medium & \\
SCL $=$ Sandy clay loam & $\mathrm{C}=$ Crumb & \\
L $=$ Loam & SBK = Subangular blockys &
\end{tabular}

TABLE 3

Particle Size Distribution of Soils Studied

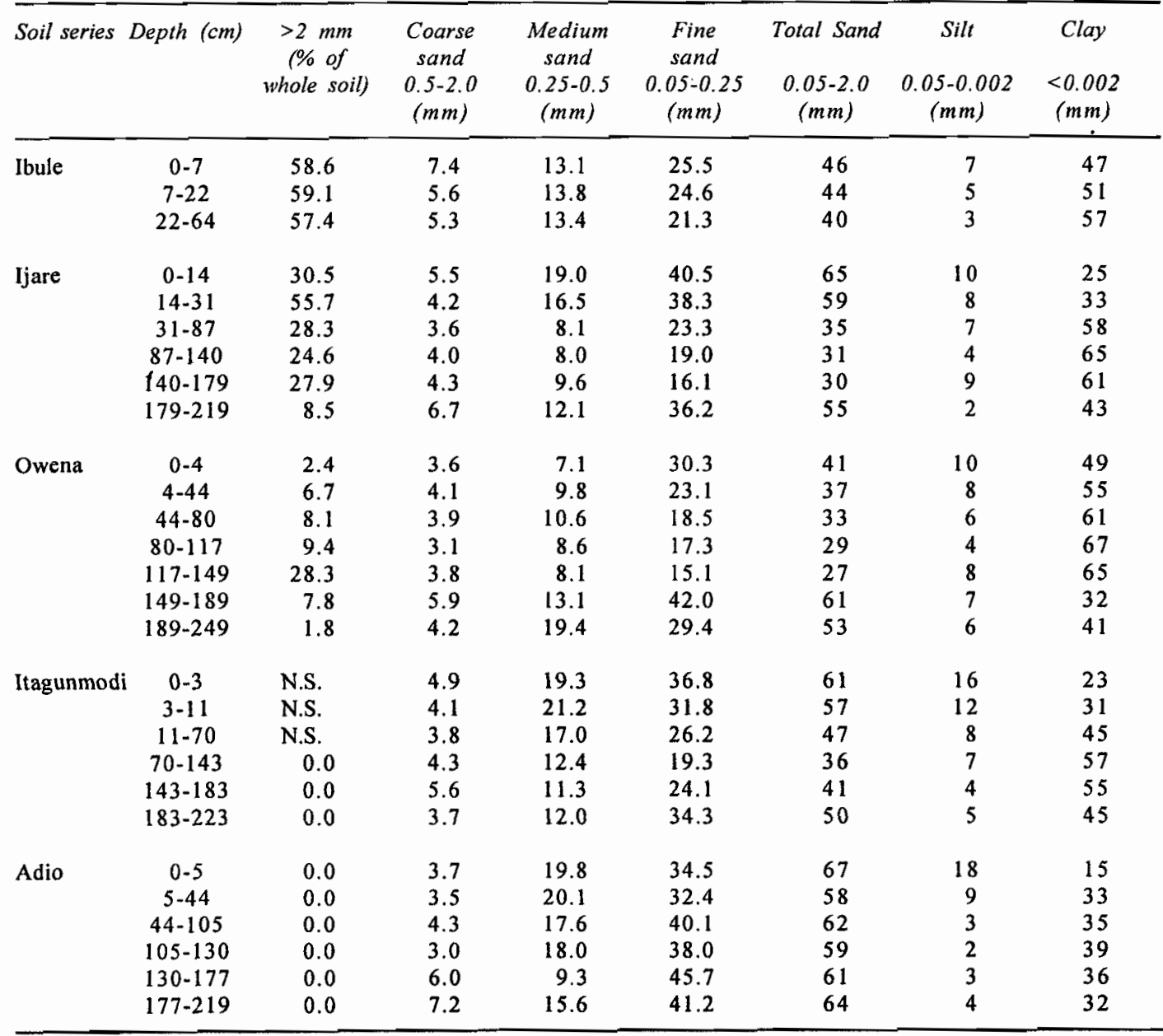

NS = present, but less than 1 per cent. 
property of soils formed in amphibolite-derived parent materials (Smyth \& Montgomery, 1962). The per cent fine sand fraction increased down the slope.

The clay content was generally high (15-67\%). It increased with depth up to the B-horizons and then decreased in the C-horizons. The pattern of clay distribution indicated an evidence of eluvial-

\section{Chemical characteristics}

The chemical characteristics of the soils are given in Tables 4, 5 and 6 . The soils varied from slightly acid to acid in reation.

A part from soils of Ibule series, the upper horizons $(0-14 \mathrm{~cm})$ of other soil profiles were slightly acid $\left(p \mathrm{H} \mathrm{H}_{2} \mathrm{O}=5.1-6.2\right)$ and the $\mathrm{B}$-horizons were acid. The acid nature of the soil could be ascribed

TABLE 4

Chemical Chaqracteristics of the Soils

\begin{tabular}{|c|c|c|c|c|c|}
\hline $\begin{array}{c}\text { Soil } \\
\text { Series }\end{array}$ & $\begin{array}{l}\text { Depth } \\
(\mathrm{cm})\end{array}$ & $\begin{array}{l}\mathrm{pH} \\
\mathrm{H}_{2} \mathrm{O}\end{array}$ & $\begin{array}{l}\text { Total } \\
N \%\end{array}$ & $\underset{\%}{\operatorname{Org.} C}$ & $\begin{array}{l}\text { Extractable } \\
P(\mathrm{mg} / \mathrm{kg})\end{array}$ \\
\hline Ibule & $\begin{array}{c}0-7 \\
7-22 \\
22-64\end{array}$ & $\begin{array}{l}5.5 \\
4.1 \\
4.0\end{array}$ & $\begin{array}{l}0.53 \\
0.27 \\
0.28\end{array}$ & $\begin{array}{l}3.32 \\
i .27 \\
1.13\end{array}$ & $\begin{array}{l}3.84 \\
2.28 \\
7.50\end{array}$ \\
\hline Ijare & $\begin{array}{c}0-14 \\
14-31 \\
31-87 \\
87-140 \\
140-179 \\
179-219\end{array}$ & $\begin{array}{l}6.2 \\
5.9 \\
5.7 \\
5.6 \\
5.3 \\
4.7\end{array}$ & $\begin{array}{l}0.48 \\
0.20 \\
0.06 \\
0.16 \\
0.10 \\
0.09\end{array}$ & $\begin{array}{l}3.30 \\
1.76 \\
0.50 \\
0.27 \\
0.04 \\
0.03\end{array}$ & $\begin{array}{r}13.92 \\
1.32 \\
0.72 \\
0.60 \\
0.60 \\
0.53\end{array}$ \\
\hline Owena & $\begin{array}{c}0-4 \\
4-44 \\
44-80 \\
80-117 \\
117-149 \\
149-189 \\
189-249\end{array}$ & $\begin{array}{l}5.6 \\
5.5 \\
5.2 \\
5.2 \\
5.0 \\
5.1 \\
5.0\end{array}$ & $\begin{array}{l}0.27 \\
0.17 \\
0.16 \\
0.11 \\
0.14 \\
0.10 \\
0.07\end{array}$ & $\begin{array}{l}1.56 \\
1.13 \\
0.18 \\
0.29 \\
0.04 \\
0.04 \\
0.02\end{array}$ & $\begin{array}{l}0.60 \\
0.60 \\
0.60 \\
0.60 \\
1.98 \\
1.05 \\
0.80\end{array}$ \\
\hline Itagunnmodi & $\begin{array}{c}0-3 \\
3-11 \\
11-70 \\
70-148 \\
148-183 \\
183-213\end{array}$ & $\begin{array}{l}6.2 \\
6.1 \\
5.3 \\
5.2 \\
5.4 \\
4.8\end{array}$ & $\begin{array}{l}0.39 \\
0.17 \\
0.17 \\
0.13 \\
0.11 \\
0.08\end{array}$ & $\begin{array}{l}2.40 \\
1.48 \\
0.82 \\
0.23 \\
0.26 \\
0.12\end{array}$ & $\begin{array}{l}5.82 \\
2.22 \\
1.80 \\
1.20 \\
1.05 \\
0.91\end{array}$ \\
\hline Adic & $\begin{array}{c}0-5 \\
5-44 \\
44-105 \\
105-130 \\
130-177 \\
177-219\end{array}$ & $\begin{array}{l}6.1 \\
5.7 \\
5.8 \\
5.7 \\
5.4 \\
5.3\end{array}$ & $\begin{array}{l}0.36 \\
0.20 \\
0.30 \\
0.17 \\
0.12 \\
0.02\end{array}$ & $\begin{array}{l}3.37 \\
0.66 \\
0.65 \\
0.52 \\
0.32 \\
0.05\end{array}$ & $\begin{array}{l}1.80 \\
3.60 \\
2.10 \\
1.60 \\
0.89 \\
0.65\end{array}$ \\
\hline
\end{tabular}

illuvial processes. Silt contentwas low (2-18\%). This is a common feature of mostsoils in Nigeria(Ojanuga, 1975 ) which could indicate advance weathering stage. to the high rate of leaching of bases which is prevalent in the humid tropics. Another cause of low $p \mathrm{H}$ values of the soils especially those under cultivation is due to crop removal of bases from the 
TABLE 5

Chemical Characteristics of the Soils

\begin{tabular}{|c|c|c|c|c|c|c|}
\hline Soil series & Depth (cm) & $\begin{array}{c}\begin{array}{c}\text { Sum of } \\
\text { bases }\end{array} \\
\\
\end{array}$ & $\begin{array}{c}\text { Extractable } \\
\text { acidity, } \mathrm{pH} 8.2 \\
\\
\ldots \ldots \ldots . . \mathrm{cmol}(+) \mathrm{kg}\end{array}$ & $\begin{array}{l}\text { CEC (sum of } \\
\text { cation, pH } 8.2 \\
\text { soill..................... }\end{array}$ & $\begin{array}{c}\text { CEC (sum of } \\
\text { cation, pH } 8.2 \\
\text { cmol }(+) / \\
\mathrm{kg} \text { clay }\end{array}$ & $\begin{array}{c}\text { Base saturation } \\
\text { CEC sum of } \\
\text { pH } 8.2 \text { bases }) \\
\text { (\%) }\end{array}$ \\
\hline \multirow[t]{3}{*}{ Ibule } & $0-7$ & 10.24 & 18.51 & 28.75 & 13.51 & 35.62 \\
\hline & $7-22$ & 2.35 & 6.52 & 8.87 & 4.52 & 26.49 \\
\hline & $22-64$ & 1.13 & 4.66 & 5.79 & 3.30 & 19.53 \\
\hline \multirow[t]{6}{*}{ Ijare } & 0.14 & 9.85 & 15.94 & 25.79 & 6.45 & 38.20 \\
\hline & $14-31$ & 8.55 & 14.05 & 22.60 & 7.46 & 37.83 \\
\hline & $31-87$ & 5.99 & 10.43 & 16.02 & 9.29 & 34.90 \\
\hline & $87-140$ & 4.54 & 8.45 & 12.99 & 8.44 & 34.96 \\
\hline & $140-179$ & 2.99 & 6.10 & 9.09 & 5.55 & 32.90 \\
\hline & $179-219$ & 1.45 & 4.00 & 5.45 & 2.34 & 26.60 \\
\hline \multirow[t]{7}{*}{ Owena } & $0-4$ & 7.47 & 13.42 & 20.89 & 10.24 & 35.86 \\
\hline & $4-44$ & 3.78 & 7.97 & 11.75 & 6.46 & 32.17 \\
\hline & $44-80$ & 3.29 & 6.66 & 9.95 & 6.07 & 66.06 \\
\hline & $80-117$ & 2.19 & 5.45 & 7.64 & 5.12 & 28.68 \\
\hline & $117-149$ & 1.81 & 4.28 & 6.09 & 3.96 & 29.70 \\
\hline & $149-189$ & 2.49 & 4.74 & 7.23 & 2.31 & 34.46 \\
\hline & $189-249$ & 1.29 & 3.72 & 5.01 & 2.05 & 25.73 \\
\hline \multirow[t]{6}{*}{ Itagunmodi } & $0-3$ & 9.15 & 24.17 & 33.32 & 7.66 & 27.46 \\
\hline & $3-11$ & 7.04 & 13.42 & 20.46 & 6.34 & 34.4 \\
\hline & $11-70$ & 4.08 & 3.99 & 8.07 & 6.34 & 34.41 \\
\hline & $70-148$ & 3.98 & 3.61 & 7.59 & 4.33 & 52.45 \\
\hline & $148-183$ & 3.25 & 5.24 & 8.49 & 4.67 & 38.30 \\
\hline & $183-213$ & 0.83 & 2.28 & 3.11 & 1.40 & 26.68 \\
\hline \multirow[t]{6}{*}{ Adio } & 0.5 & 10.52 & 18.23 & 28.75 & 4.31 & 36.59 \\
\hline & $5-44$ & 4.39 & 7.67 & 12.01 & 3.96 & 35.89 \\
\hline & $44-105$ & 3.91 & 7.66 & 11.57 & 4.05 & 33.79 \\
\hline & $105-130$ & 1.73 & 3.98 & 5.71 & 2.23 & 30.31 \\
\hline & $130-177$ & 1.63 & 3.88 & 5.51 & 1.98 & 29.56 \\
\hline & $177-2.19$ & 3.20 & 7.06 & 10.26 & 3.28 & 31.19 \\
\hline
\end{tabular}

soil solution. This disturbs the equilibrium which exists between bases in the soil solution and exchangeable bases on the exchange sites. Bases, therefore, move from the soil into sofution in order to re-establish the equilibrium. The values ofall the exchangeable bases decreased with increasing depth. The CEC (by sum of cation, at $p \mathrm{H} \mathrm{8.2)} \mathrm{values}$ ranged from 3.11 to $28.75 \mathrm{cmol}(+)$ per kg soil while $\mathrm{CEC}$ by $\mathrm{NH}_{4} \mathrm{OAc}$ values varied from 2.32 to 15.19 cmol(+)per kg soil. 
TABLE 6

Chemical Characteristics of the Soils

\begin{tabular}{|c|c|c|c|c|}
\hline Soil series & $\operatorname{Depth}(\mathrm{cm})$ & $\begin{array}{c}C E C \text { by } \mathrm{NH}_{4} \mathrm{OAc} \\
\text { at } \mathrm{pH} 7.0 \\
(\mathrm{cmol}(+) / \mathrm{kg} \text { soil) }\end{array}$ & $\begin{array}{c}\mathrm{CEC} \text { by } \mathrm{NH}_{4} \mathrm{OAc} \\
\text { at } \mathrm{p} H 7.0 \\
\text { (cmol( }+ \text { ( ) } / \mathrm{kg} \text { clay })\end{array}$ & $\begin{array}{c}\text { Base saturation } \\
\text { on } C E C \text { by } \mathrm{NH}_{4} O A C \\
\text { basis (I \%) }\end{array}$ \\
\hline Ibule & $\begin{array}{c}0-7 \\
7-22 \\
22-64\end{array}$ & $\begin{array}{r}15.19 \\
4.63 \\
2.51\end{array}$ & $\begin{array}{l}7.14 \\
2.36 \\
1.43\end{array}$ & $\begin{array}{l}67.4 \\
50.8 \\
45.1\end{array}$ \\
\hline Ijare & $\begin{array}{c}0-14 \\
14-31 \\
31-87 \\
87-140 \\
140-179 \\
179-219\end{array}$ & $\begin{array}{r}12.30 \\
11.48 \\
11.90 \\
10.19 \\
7.95 \\
3.63\end{array}$ & $\begin{array}{l}3.07 \\
3.79 \\
6.90 \\
5.40 \\
4.85 \\
1.56\end{array}$ & $\begin{array}{l}80.1 \\
74.5 \\
47.0 \\
44.7 \\
37.6 \\
39.9\end{array}$ \\
\hline Owena & $\begin{array}{c}0-4 \\
4.44 \\
44-80 \\
80-117 \\
117-149 \\
149-189 \\
189-249\end{array}$ & $\begin{array}{l}9.69 \\
5.56 \\
6.21 \\
3.41 \\
3.09 \\
5.62 \\
3.64\end{array}$ & $\begin{array}{l}4.75 \\
3.06 \\
3.79 \\
2.29 \\
2.29 \\
1.80 \\
1.49\end{array}$ & $\begin{array}{l}77.1 \\
68.0 \\
53.0 \\
64.3 \\
58.6 \\
44.3 \\
35.4\end{array}$ \\
\hline Itagunmodi & $\begin{array}{c}0-3 \\
3-11 \\
11-70 \\
70-148 \\
148-183 \\
183-214\end{array}$ & $\begin{array}{r}10.43 \\
10.35 \\
6.96 \\
7.47 \\
6.32 \\
2.32\end{array}$ & $\begin{array}{l}2.40 \\
3.21 \\
3.13 \\
4.26 \\
3.97 \\
1.04\end{array}$ & $\begin{array}{l}87.7 \\
68.0 \\
58.6 \\
53.3 \\
51.4 \\
35.8\end{array}$ \\
\hline Adio & $\begin{array}{c}0-5 \\
5-44 \\
44-105 \\
105-130 \\
130-177 \\
177-219\end{array}$ & $\begin{array}{r}11.59 \\
6.13 \\
6.77 \\
3.35 \\
3.25 \\
7.29\end{array}$ & $\begin{array}{l}1.74 \\
2.02 \\
2.37 \\
1.31 \\
1.17 \\
2.33\end{array}$ & $\begin{array}{l}90.8 \\
70.3 \\
57.8 \\
51.6 \\
50.2 \\
43.9\end{array}$ \\
\hline
\end{tabular}

Total $\mathrm{N}$ content of the soils was generally low (0.02-0.53\%). Organic carbon contentranged from 0.02 to 3.37 percent. The upper $0-14 \mathrm{~cm}$ of the soil profiles had the highest value of organic carbon. Extractable P content varied from 0.28 to $13.92 \mathrm{mg} /$ $\mathrm{kg}$. These values were quite low. The low $P$ values could be attributed to the low $P$ content of massive amphibolite which is the parent rock of the soils studied (Ajayi, 1980). The patterns of distribution of available $P$ and organic $C$ were similar, and this might infer sifnificant organic or biocycled $P$ in the soils.

Soil classification

The soils were classified as Ibule, Ijare, Owena, Itagunmodi and Adio series according to local classification system by Smyth \& Montgomery (1962)(Fig. 2). The soils were classified according to the FAO/UNESCO soil map legend (FAO-UN, 1988), and Soil Taxonomy (Soil Survey Staff, 1987) (Table 7).

The soil of pedon Ita 01 (Ibule series) fitted the concept of Ferralsol (of FAO/UNESCO soil map 
TABLE 7

Classification of the Soils Studied

\begin{tabular}{|c|c|c|c|}
\hline $\begin{array}{l}\text { Soil } \\
\text { profile }\end{array}$ & $\begin{array}{c}\text { Local } \\
\text { classification }\end{array}$ & $\begin{array}{l}\text { FAO/UNESCO } \\
\text { soil map legend }\end{array}$ & Soil taxonomy \\
\hline Ita 01 & Ibule series & Rhodic Ferralsol & Rhodic Eutrustox \\
\hline Ita 02 & Ijare series & Ferric Acrisol & Rhodic Kanhaplustult \\
\hline Ita 03 & Owena series & Rhodic Nitisol & Rhodic Kandiustult \\
\hline Ita 04 & $\begin{array}{l}\text { Itagunmodi } \\
\text { series }\end{array}$ & Haplic Lixisol & Typic Haplustult \\
\hline Ita 05 & Adio series & Gleyic Lixisol & Oxyaquic Kandiudult \\
\hline
\end{tabular}

legend) and it was classified as Rhodic Ferralsol. This was because the soil had a ferralic B-horizon; clayey texture, more than $30 \mathrm{~cm}$ thick, $\mathrm{CEC}$ by $\mathrm{NH}_{4}$ OAc less than $16 \mathrm{cmol}(+) / \mathrm{kg}$ clay, silt-clay ratio value less than 0.2 and less than 10 per cent weatherablemineral (Osei, 1992). The ferralic B had reddish colour (2.5 YR). All the soils except Ibule series had ustic moisture regime (Table 1) and hence, they belong to Ustox sub group of the Soil Taxonomy. Ibule series typified by pedon Ita 01 had characteristics to be classified as Rhodic Eutrustox.

Soil of pedon Ita 02 (Ijare series) had B-horizon which had CEC (by $\mathrm{NH}_{4} \mathrm{OAc}$ ) values that were less than $24 \mathrm{cmol}(+)$ per kg clay and base saturation (on $\mathrm{CEC}$ by $\mathrm{NH}_{4} \mathrm{OAc}$ basis) values of less than 50 per cent (Table 6). The soil also had iron concretions, ferric properties (Table 2) and it classified as Ferric Acrisol (of FAO/UNESCO soil map legend). According to Soil Taxonomy soil typified by Ita 02 was Rhodic Kanhaplustult.

Sub soil of soil of pedon Ita 03 (Owena series) had nitic properties and it also had red to dusky red argic $\mathrm{B}$, hence it fitted into Rhodic Nitisol of FAO/ UNESCO soil map legend. By Soil Taxonomy, the soil was classified as Rhodic Kandiustult because it had CEC (by $\mathrm{NH}_{4} \mathrm{OAc}$ ) value of $<4 \mathrm{cmol}(+)$ per $\mathrm{kg}$ clay in the argillic B-horizon (Table 6) and percentage clay distribution did not decrease from its maximum amount by as much as 20 percent with a depth of $150 \mathrm{~mm}$ from the soil surface.
The occurrence of $\mathrm{B}_{\mathrm{t}}$-horizons in the soil of pedon Ita 04 (Itagunmodi series) testified to the presence of argic B-horizon. It was classified as Lixisol. The soil lacked ferric properties so it belonged to Haplic Lixisol of FAO/UNESCO soil map legend. According to Soil Taxonomy, Typic Haplustult is typified by pedon Ita 04.

Soil of pedon Ita 05 (Adio series) was saturated with water during the rainy season. This was supported by the presence of mottles in B-horizons (Table 2) and shallow water table as observed in the field. Adio series fitted closely into the requirements for classification as Gleyic Lixisols, according to $\mathrm{FAO} /$ UNESCO soil map legend. It was because it had udic moisture regime and its argillic B-horizon had $\mathrm{CEC}$ (by $\mathrm{NH}_{4} \mathrm{OAc}$ ) value of less than $16 \mathrm{cmol}(+) /$ kg clay (Table 6 ).

\section{Conclusion}

On the basis of this study it appeared that the characteristics of the soils were primarily determined by the nature of the underlying rock. Topographical changes exerted secondary effects only. Pedogenic processes believed to have taken place were lessivation as evidenced by $\mathrm{B}_{\mathrm{t}}$-horizons and ferruginization.

The soil of the summit of the toposequence was classified as Ferralsol while that of the lower slope and valley bottom belonged to Lixisol. Soils of the upper and middle slopes typified Acrisol and Nitisol respectively, according to FAO/UNESCO soil map legend. All the soils (except Ibule series) characteristically had clay bulge in the middle layers; $\mathrm{B}_{\mathrm{t}}$ horizons and they (except Adio) also had ustic moisture regime. The soils of the summit classified as Oxisol, while all the other soils belonged to Ultisol, according to Soil Taxonomy.

\section{Acknowledgement}

The author thanks the Federal Government of Nigeria forsponsoringhim financially at the Obafemi 
AwolowoUniversity, Ile-Ife to undertake thisstudy.

\section{REFERENCES}

Ajayi, T. R. (1980) On geochemistry and origin of the amphibolite in Ife-Ilesha area. J. Min. Geol. 17(2), 179-196.

Beinroth, F. H. (1982) Some highly weathered soils of Puerto Rico. I. Morphology, formation and classification. Geoderma 27, 1-73.

Bigham, J. M., Golden, D. C., Boul, S. W., Weed, S. B. \& Bowen, L. H. (1978) Iron oxide mineralogy of well drained Ultisols and Oxisols. 2. Influence on colour, surface area and phosphate retention. Soil Sci. Soc. Am. J. 42, 825-830.

Boyoucos, G. J. (1962) Hydrometer method improved for making particle size analysis of soils. Soil Sci. Soc. Am. Proc. 26, 464-465.

Bray, R. H. \& Kurtz, L.T.(1945) Determination of total organic and available forms of phosphorus in soil. Soil Sci. 59, 39-45.

Bremner, J. M. (1965) Total nitrogen. In Methods of soil analysis (ed. C. A. Black). Agron. Abstrs 9(2) Am. Soc. Agron. 1149-1178.

Chhabbra, R., Pleysier, J. L. \& Cremers, A. (1975) The measurement of the cation exchange capacity and exchangeable cations in soils: anew method. Proc. int. Clay Conf., Mexico. 10, 13-28.

Davey, B. G., Russel, J. D. \& Wilson, M. J. (1975) Iron oxide and clay minerals and their relation to colours of red and yellow podzolic soils near Sydney, Australia. Geoderma. 14, 125-138.

Folster, H., Moshrefi, N. \& Ojanuga, A. G. (1971) Ferralitic pedogenesis on metamorphic rocks in southwestern Nigeria. Pedologie XX 7, 95-124.

FAO (1977) Guidelines for soil profile description, 2nd ed., 66 pp. Rome: FAO.

FAO,UN (1988) FAO/UNESCO Soil Map of the World, Revised Legend. (World Soil Resources Report 60) Rome: FAO.

Harpstead, M. I. (1974) The classification of some
Nigerian soils. Soil Sci. $116(6), 437-442$.

Lietzke, D. A. \& Whiteside, E.P. (1981)Characterization and classification of some Belize soils. Soil Sci. Soc. Am. J. 45 (2), 378-385.

Ojanuga, A. G. (1975) Morphological, physical and chemical characteristics of soils of Ife and Ondo Areas. Nigeria J. Sci. 9, 225-269.

Ojo-Atere, J. O. \& Oladimej:, M. O. (1983) Characteristics and classification of some upper slope soils in savanna ecosystem of south-western Nigeria. Ife $J$. Agric. 5, 1-22.

Osei, B. A., (1992) Sand mineralogy and related properties of some soils in south-western Nigeria. Communs Soil Sci. Pl. Analysis 23 (15 \& 16), 18151826.

Peech, M., Alexander, L. T., Dean, L. A. \& Reed, J. F. (1947) Methods of soil analysis for soil fertility investigations. US Dep. Agric. C.T. 57. 25 pp.

Periaswamy, S. P. \& Ashaye, T. I. (1982) Updated classification of some south-western Nigerian soils. Ife J. Agric. 4 ( 1 \& 2), 25-36.

Smyth, A. J. \& Montgomery, R. F. (1962) Soils and Land Use in Central Western Nigeria, pp. 41-167, Lagos: Government Printer.

Soil Survey Staff (1981) New Soil Survey Manual. Designations for Horizons and Layers, pp. 39-51, Washington, DC: Government Printer.

Soil Survey Staff (1987) Keys to Soil Taxonomy (3rd printing) SMSS Technical Monograph No. 6. Ithaca, New York: SMSS.

Torrent, J., Schwertmann, V., Fechter, H. \& Alferez, F. (1983) Quantitative relationships between soil colour and hematite content. Soil Sci. $136(6), 356-$ 357.

Vine, H. (1951) Provisional Soil Map and List of Soil Fascs in Nigeria. Report of Agriculture Department, Ibadan.

Walkley, A. \& Black, I. A. (1934) An examination of the Degtjareff method for determining soil organic matter and proposed modification of the chromic acid titration method. Soil Sci. 37, 29-38. 